\title{
Ensuring the quality of the connection of layers from different metals in the manufacture of bietallic tubular elements by drawing
}

\author{
R. Borys • V. Titov \\ Igor Sikorsky Kyiv Polytechnic Institute, Kyiv, Ukraine
}

Received: 04 March 2019 / Accepted: 12 March 2019

\begin{abstract}
A complex technique of theoretical and experimental research of the process of manufacturing bimetallic tubular elements by drawing with thinning of a two-layer billet of dissimilar metals using the relief of the boundary surface is presented. Using the theory of plastic flow, a mathematical model was developed for the deformation of the joint drawing process with thinning of two dissimilar metals with heating under conditions of a plane deformed state, which allowed to establish the relationship between the parameters of the stress-strain state on the boundary surface and the degree of deformation of the thinning with the original geometric parameters of the workpiece to fill the relief of the boundary surface.
\end{abstract}

Keywords: stress-strain state, the components of the stress and strain rate, dissimilar metals, the boundary surface, the degree of deformation, surface topography, extract with thinning, two-layer preform, the geometric parameters of the original piece

\section{Introduction}

Modern trends in the development of machine-building industry is characterized by increased requirements for quality and performance of products at relatively low cost and cost. To ensure the effectiveness of engineering products in their designs are widely used a combination of different materials to provide the necessary specific functional properties that are not inherent in any of the elements separately. For these purposes, widely used are layered metal elements of tubular shape (bimetallic tubular elements - BTE), which are used as adapters for connecting pipelines in fuel systems, as well as for connecting in the construction of high-tech engineering products from dissimilar metals such as aluminum, steel, titanium and others.

The production of BTE is realized by diffusion pressure welding at high temperatures. For this purpose, various processes are used, such as rolling, drawing, drawing, and others, which are characteristic of mass and mass production of [1-10]. In modern conditions, to ensure the competitiveness of products on the market, it is necessary to ensure the efficiency of sales and mobility of BTE production in small-scale and individual production. In papers [11-14], the authors proposed the most efficient process for obtaining a BTE by an extractor with thinning of dissimilar metals from sheet blanks.

The disadvantage of this process is not stable formation of the diffusion compound. Improving the strength of the joint is possible by using combined methods, such as a combination of diffusion and mechanical connection. In this case, the surfaces of dissimilar metals are connected by a curvilinear generator, which increases the shear strength of the joint.

\section{State of Question and Statement of the Research Problem}

Theoretical foundations and analysis of energy-power parameters of process of drawing with thinning of cylindrical articles devoted to the work [15-20].

In the works [21-24] authors considered the analysis of the kinematic parameters and the deformation characteristics of double layer forming workpieces of dissimilar metals for the conditions of hot deformation with the account of friction forces on contact surfaces when the drawing with thinning. In these works, the connection of layers was considered by a rectilinear generator. The use of a curvilinear generator changes the scheme of the stress state. Therefore, the theoretical analysis of the calculation of the parameters of the process of joint drawing with thinning, which are necessary for the formation of relief elements on the boundary surface is an urgent scientific and technical problem.

R. Borys

boris_ryslan@ukr.net 
In this paper, the authors consider the results of calculation and testing of the process of deformation of a twolayer billet by drawing with thinning, taking into account the geometry of the deforming tool, changes in the thickness of metal layers that affect the stress-strain state on the boundary surface and the change in speed in the deformation zone to form relief elements.

The aim of the work is to substantiate the conditions of connection of dissimilar metals on the relief boundary surface of bimetallic tubular elements by drawing with thinning.

\section{Main Content of the Paper}

Implementation of the diffusion-mechanical connection was carried out by connecting layers of dissimilar metals, one of which has a curved relief, which during the connection is filled with metal less durable layer (Fig. 1, $a$ ). To determine the filling of the elements of the relief shape of the boundary surface, it is necessary to determine the contact compressive stresses and select the necessary optimal relief shape, which will be completely filled under the action of compressive stresses during drawing with the thinning of a two-layer workpiece.

The scheme of interaction of layers of dissimilar metals at drawing with thinning for diffusion-mechanical connection and the design scheme of process of filling of a single constructive element of a relief of a boundary surface is presented in Fig. $1 a, b[10]$.

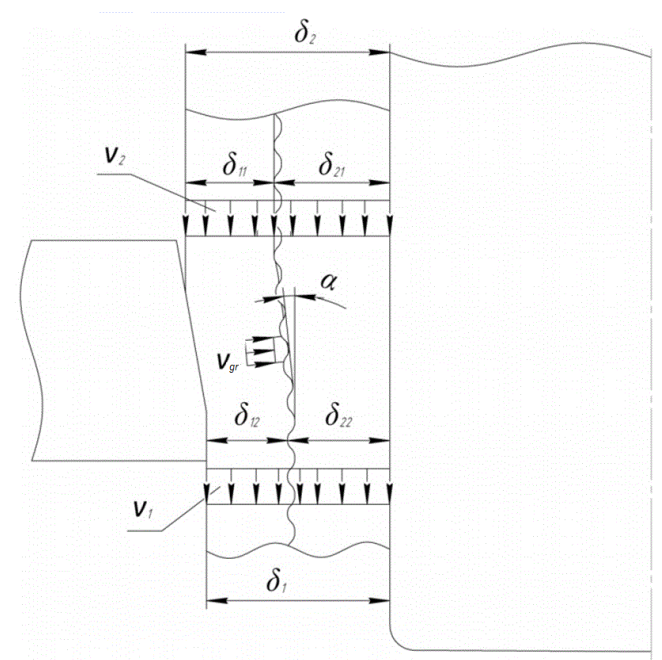

$a$

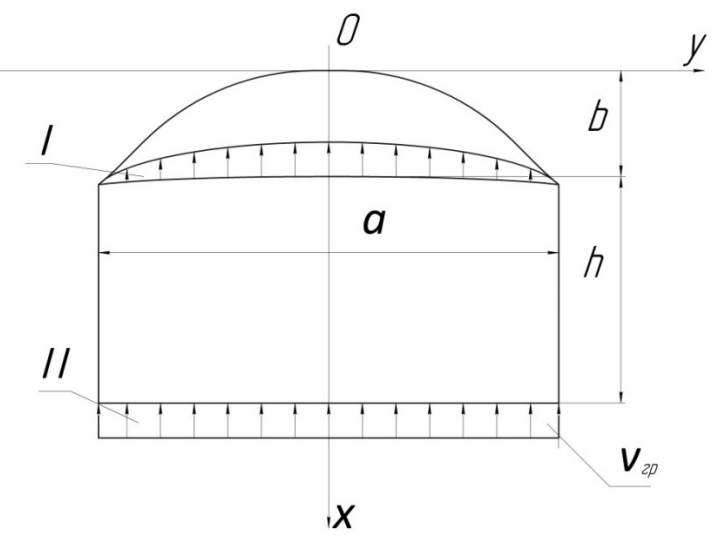

$b$

Fig. 1. Scheme of interaction of layers of dissimilar metals in drawing with thinning for diffusion-mechanical connection $(a)$ and the process of filling a single structural element of the boundary surface relief $(b)$

We consider the problem to be flat. Plastic flow of the metal under consideration in the plane of the $X O Y$. The junction of the material walls is approximated by a parabolic function.

Consider the area of the workpiece width $a$ and height $h$, where $h$ - half of the thickness of the outer layer of the metal after drawing with thinning according to accepted methods [7]. When filling the radius of the interface I must touch the surface of the relief form, that is, on the axis of symmetry to carry out a path equal to $b$.

We believe that the vertical component of the velocity on the surface $I$, depending on the $x$ coordinate, changes according to the parabolic law (Fig. 1), and on the surface II speed is constant and equal to $V_{g r}$., where $V_{g r}$. - the speed of movement of the tool, which depends on the angle of the matrix. Then the velocity field has the form:

For theoretical analysis, we will use a technique that uses General laws of continuum mechanics. The vertical component of the velocity $V_{x}$ is defined as:

$$
V_{x}=V_{x_{I}}+V_{x_{I I}}
$$

where $V_{x_{I}}, V_{x_{I I}}$ - speeds of movement of points of material which belong to surfaces $I$ and $I I$ respectively (Fig. 2). We believe that on the surface $I$, depending on the coordinate $x$, the velocity changes according to the parabolic law, and on the surface $I I$, the velocity is constant and equal to $V_{g r}$. where $V_{g r}$. - the speed of movement of the tool, which depends on the angle of the matrix.

$$
V_{x}=A\left(\frac{4 y^{2}}{a^{2}}-1\right)\left[\frac{b-x}{h}+1\right]+\frac{V_{g r}}{h}(b-x)
$$

where $A$ - the speed of movement of the workpiece point, which is on the surface $I$.

$$
A=\frac{3}{\sqrt{2}} V_{g r}
$$


Horizontal $V_{x}$ is found from the continuity equation:

$$
\frac{d V_{x}}{d x}=-\frac{d V_{y}}{d y}
$$

After performing some transformations, we obtain:

$$
V_{y}=\frac{V_{g r} y}{2 h}\left(\frac{4 y^{2}}{a^{2}}-1\right)
$$

Therefore, functions (3) and (4) define a field of the velocities of the parts of the metal when it is extruded.

We calculate the generalized strain rate using the assumption that the shear component of the strain rate is in the direction of the coordinate axes:

$$
V_{y}=\frac{2}{\sqrt{3}} \frac{V_{g r}}{h}\left(\frac{6 y^{2}}{a^{2}}-\frac{1}{2}\right)
$$

The stiffness coefficient is calculated taking into account the fact that the plastic deformation is carried out in the heated state, then we obtain:

$$
\mu_{i}=\frac{\sigma_{S} h}{2 \sqrt{3}\left(\frac{6 y^{2}}{a^{2}}-\frac{1}{2}\right)}
$$

where $\sigma_{s}$-yield strength of the material with lower mechanical properties corresponding to the processing temperature range.

The equations of plastic flow taking into account the obtained functions (2) and (5) have the form:

$$
\begin{gathered}
\frac{\partial \sigma}{\partial x}=\rho\left(\frac{\partial V_{x}}{\partial t}+V_{x} \frac{\partial V_{x}}{\partial x}\right)-\mu_{i} \frac{\partial^{2} V_{x}}{\partial x^{2}}-2 \frac{\partial \mu_{i}}{\partial x^{2}} \frac{\partial V_{x}}{\partial x} \\
\frac{\partial \sigma}{\partial y}=\rho\left(\frac{\partial V_{y}}{\partial t}+V_{x} \frac{\partial V_{y}}{\partial x}+V_{y} \frac{\partial V_{y}}{\partial y}\right)-\mu_{i} \frac{\partial^{2} V_{y}}{\partial x^{2}}-\frac{\partial \mu_{i}}{\partial x^{2}} \frac{\partial V_{y}}{\partial x}
\end{gathered}
$$

where $\rho$-the density of the material with lower mechanical properties.

The mean stress in the volume is deformed:

$$
\sigma=\int_{x} \frac{\partial \sigma}{\partial x} d x+\int_{y} \frac{\partial \sigma}{\partial y} d y
$$

At the next stage, we calculate the stress-strain state at the boundary of the relief, for this we determine the speed of movement (the scheme is shown in Fig.1).

Then write the equality:

$$
\delta V_{1}=\delta V_{2}
$$

Taking into account the thickness of materials and their properties, we calculate the deformation coefficient of each material:

$$
\frac{\sigma_{s T i} S_{T i}}{\sigma_{s A l} S_{A l}}=K
$$

Taking into account the coefficient $K$, we can say that the workpiece with lower mechanical properties will be deformed by $K$ times more, so we calculate the deformation rate of the outer layer:

$$
V_{11}=V_{1} \frac{\delta_{12}}{\delta_{11}} \frac{1}{K}
$$

Given that $V_{11}=V_{g r}$ but also depends on the angle $\alpha$, so we obtain:

$$
V_{g r}=\frac{V_{11}}{\cos \alpha}
$$

Suppose that $V_{g r}$ is a constant $\left(V_{g r}=\right.$ const $)$ along the boundary of a layer on a unit area of relief. Then, making some transformations for the derivatives of the average voltage for the variables $x$ and $y$, we obtain:

$$
\frac{\partial \sigma}{\partial y}=\frac{V_{11} y}{2 h \cos \alpha}\left(\frac{4 y^{2}}{a^{2}}-1\right)\left[\frac{V_{11}}{h \cos \alpha}\left(\frac{6 y^{2}}{a^{2}}-\frac{1}{2}\right)\right]+\frac{6 \sigma_{s} y}{a \sqrt{3}\left(\frac{6 y^{2}}{a^{2}}-\frac{1}{2}\right)}
$$




$$
\begin{aligned}
& \frac{\partial \sigma}{\partial x}=-\frac{V_{11} y}{h \cos \alpha}\left[\frac{3}{2}\left(\frac{4 y^{2}}{a^{2}}-1\right)(b+h-x)+(b-x)\right]\left[\frac{V_{11}}{h \cos \alpha}\left(\frac{6 y^{2}}{a^{2}}-\frac{1}{2}\right)\right]+ \\
& \left.+\frac{6 V_{11}^{2} y^{2}}{h^{2} a^{2} \cos ^{2} \alpha}\left(\frac{4 y^{2}}{a^{2}}-1\right)(b+h-x)-\frac{6 \sigma_{x}(b+h-x)}{a^{2} \sqrt{3}\left(\frac{6 y^{2}}{a^{2}}-\frac{1}{2}\right)}\right]\left[1-\frac{12 y^{2}}{a^{2}\left(\frac{6 y^{2}}{a^{2}}-\frac{1}{2}\right)}\right]
\end{aligned}
$$

After integrating the obtained expressions, we write an approximate equation for finding the axial stress $\sigma_{x x}$ at the point $x=0$ of the integration constant $C$, which is included in the equation, we determine from the condition $\sigma_{x x}=0$ at $x \leq b$.

After determining the integration constant $C$, you can write an approximate equation to find the magnitude of the stress $\sigma_{x x}$ :

$$
\sigma_{x x}=\frac{3 \sigma_{s} a b(b+2 h)}{\left(12 y^{2}-a^{2}\right)}\left[\frac{12 y^{2}}{12 y^{2}-a^{2}}-1\right] .
$$

Equation (17) allows us to determine the compression stress $\sigma_{x x}$ on the contact surface of the relief, applied to the surface of a solid, when compressed with a softer layer.

Based on the solution of equations (17), a graph of the specific compression force on the contact surface in the zone of a single relief is obtained (Fig. 2) for the composition of aluminum layer + steel. The value of the required pressure on the outer surfaces of the layers in the deformation zone, to fully fill the relief is determined by the maximum value $\sigma_{x x} \max$.

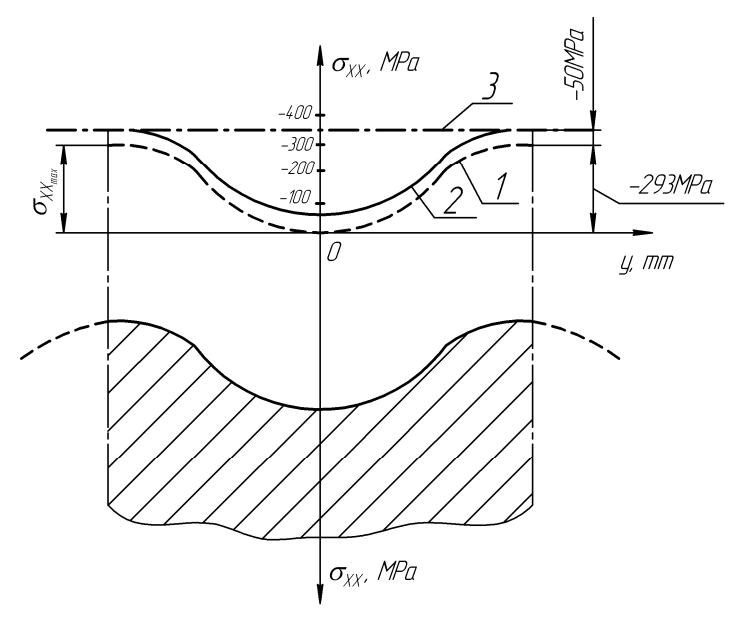

Fig. 2. Distribution of normal stresses on the surface layers of metals in the area of individual relief: 1 - the distribution of normal stress on the boundary surface necessary for filling in isolated terrain; 2 - normal voltage that must be generated on the boundary surface of the unit relief needed for the connection diffusion layers of metals; 3 - magnitude of the normal stresses on the outer surfaces of the layers

The theoretical analysis of the evaluation of the conditions of the compound layers of dissimilar metals in the extraction with thinning showed that:

1. For full filling unit relief you need compression, which in magnitude is equal to $\sigma_{x x m a x}$. in place of the maximum height of a single elevation (Fig. 2, curve 1);

2. To create a diffuse connection, the minimum compression at each point of the boundary surface of the layers must exceed $\sigma_{x x}$ by a value of $\sigma_{0}=50 \mathrm{MPa}$;

3. To ensure this condition requires that the minimum and maximum heights of a single terrain contact pressure $\sigma_{x x} \geq \sigma_{0}=-50 \mathrm{MPa}$ (Fig. 2 curve 2);

4. To ensure the condition of the diffusion compound in this case, the compression acting on the outer surface must be equal to $\sigma_{x x m a x}+(-50) \mathrm{MPa}$, which is in this case $-350 \mathrm{MPa}$ (Fig. 2, curve 3).

In the system of CAD / CAE Simufact Forming 12.0 the calculation of the stress state of a two-layer workpiece in the process of drawing with thinning, using the topography of the boundary surface.

The scheme of the process of drawing with thinning is shown in Fig. 3. It was assumed that an elongated twolayer cup with a pre-applied relief on the boundary surface of the stronger metal is pulled through the matrix with a given degree of compression. When drawing with thinning, a matrix with a constant angle $\alpha$ was used (Fig. 4). 


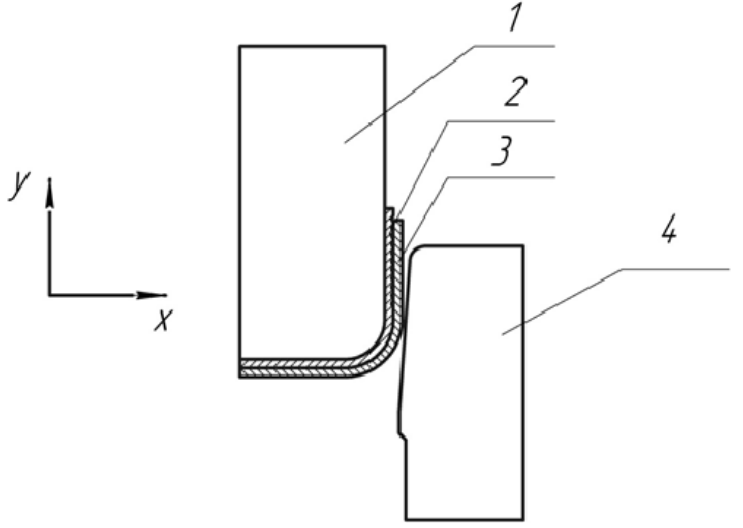

Fig. 3. Calculation scheme of the joint drawing process: 1 -punch; 2, 3-the inner and outer layers of the workpiece, respectively; 4 - matrix

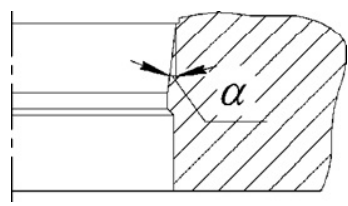

Fig. 4. The shape of the working surface of the matrix for drawing with thinning at a given angle $\alpha$

The punch and the matrix were considered absolutely rigid. When calculating the punch, the speed and time were set. Zero displacement and velocity were set for the matrix. Adopted elastic-plastic model of metal layers. The coefficient of friction on the boundary surface of the metal layers $\mu_{1}=0.3$, the coefficient of friction between the workpiece and the working surface of the matrix $\mu_{2}=0.05$, the coefficient of friction between the punch and the workpiece $\mu_{3}=0.05$ Mechanical properties of the metal layers meet the heating temperature of the workpiece $420 \pm 10^{\circ} \mathrm{C}$. The angle that determines the center of deformation is $\alpha=7^{\circ}$ compression degree $44 \%$.

On Fig. 5 the results of calculation of stress and strain distribution in the deformation zone are presented.

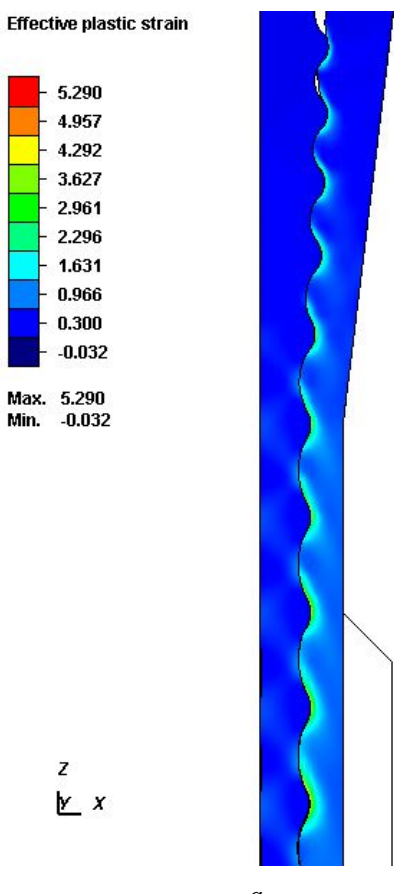

$a$

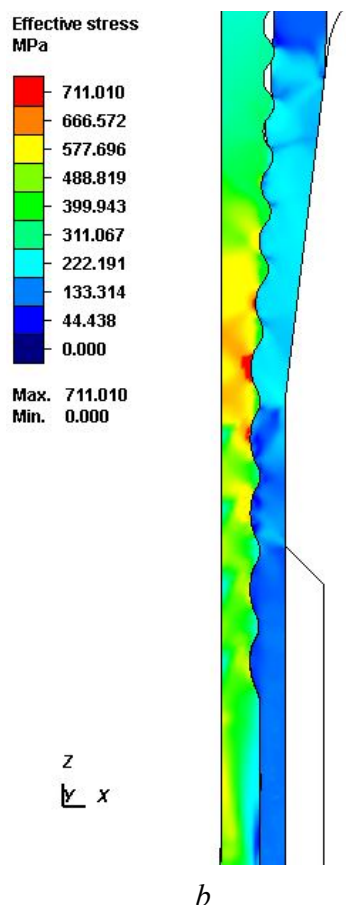

$b$

Fig. 5. Distribution of stress intensity $(a)$ and the intensity of deformations in the hearth of deformation $(b)$ the degree of compression of $44 \%$

As a result of compression of an aluminum layer on stronger steel layer of steel, elements of a relief are completely filled. The obtained calculated data with the use of FEM are sufficiently satisfied with the theoretical stresses obtained by the formula (3). Material with large mechanical properties is deformed to a lesser extent, but the boundary surface is distorted.

On Fig. 6 presents the experimental samples of two-layer blanks after the drawing without thinning and with thinning of the wall with compression is $44 \%$, and Fig. 7 presents the experimental sample BTE. 


\begin{tabular}{|c|c|c|c|c|}
\hline Dawing without thinning & Drawing with thinning & $\begin{array}{c}\text { System: } \\
\text { outer layer+ } \\
\text { inner layer }\end{array}$ & $\begin{array}{l}\text { Deformation } \\
\text { temperature, } \\
{ }^{\circ} \mathrm{C}\end{array}$ & 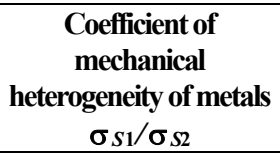 \\
\hline & & $\begin{array}{l}\text { AISI } 304 \text { (stainless steel } \\
\text { layer) }+5083 \text { (aluminum } \\
\text { layer) }\end{array}$ & $420 \pm 10$ & 0.78 \\
\hline & & $\begin{array}{c}\text { CuZn37 (a layer of } \\
\text { brass)+ } \\
\text { AISI } 304 \text { (stainless steel }\end{array}$ & $650 \pm 10$ & 0.58 \\
\hline & & $\begin{array}{c}\mathrm{Gr} 1 \\
\text { (the titanium layer)+ } \\
5083 \text { (aluminum layer) }\end{array}$ & $420 \pm 10$ & 0.42 \\
\hline
\end{tabular}

Fig. 6. Two-layer workpieces BTE (cups) after drawing

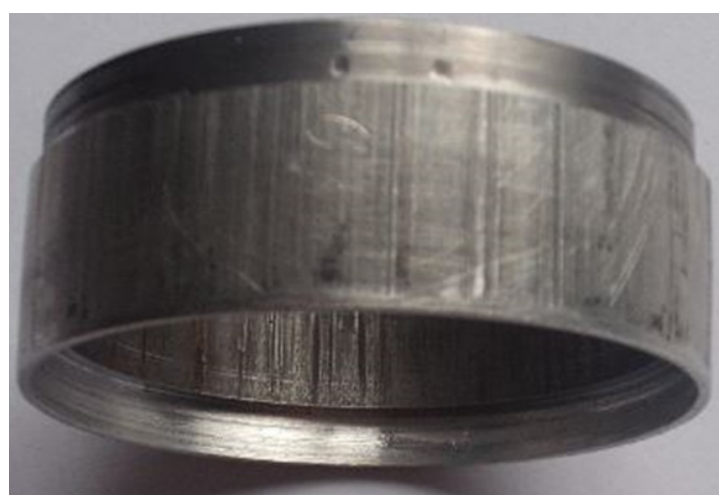

Fig. 7. Experimental sample of bimetallic tubular element

As a result of experimental research the scheme of technological process of production of BTE by joint drawing with thinning of dissimilar metals in the heated state is proved, the basic theoretical dependences for calculation of technological parameters and results of numerical modeling are confirmed. It is shown that the calculated results differ from the experimental results no more than $9 . . .11 \%$ for different values of the coefficient of mechanical heterogeneity.

\section{Conclusions}

1. On the basis of accepted assumptions and hypotheses which were accepted for calculation the theoretical model of filling of a single element of a relief of a boundary surface is developed and the speed of flow of metal with smaller characteristics of durability is defined.

2. The numerical simulation of the process of joint drawing with the thinning of two dissimilar metals in the heated state using the relief of the boundary surface on the material with high strength characteristics in the software package CAD / CAE Simufact Forming 12.0 is performed. Analysis of the stress-strain state showed that on the boundary surface of a single relief observed unevenness of stress and plastic deformation on the surface, which leads to a difference in the filling element of the boundary surface after the removal of compressive loads due to elastic deformation, as well as in the center of deformation creates conditions that contribute to the filling of the boundary surface material with lower strength characteristics. 
3. Depending on the angle of inclination of the matrix (the active drawing angle $\alpha$ ) and changes in the degree of compression varies the possible degree of filling of the relief elements. With increasing degree of compression the increase of tension deformation, which leads to better filling of the relief elements. The optimum angle of inclination of the matrix corresponds to $10-15^{\circ}$.

4. The drawing with the thinning of the bimetallic cup with the elements of the boundary surface relief in the hot state was experimentally worked out and confirmed by numerical and theoretical calculations of the conditions for filling the elements of the boundary surface relief with a material with lower strength characteristics. As shown by numerical and experimental calculations, the relief elements can be under-filled, this is due to the geometric parameters (the angle of the matrix and the shape of the relief of the boundary surface).

\title{
Обеспечение качества соединения слоев из разнородных металлов при изготовлении биметаллических трубчатых элементов вытяжкой
}

\author{
P.С. Борис, В.А. Титов
}

Аннотация. Представлена комплексная методика теоретического и экспериментального исследования процесса изготовления биметаллических трубчатых элементов вытяжккой с утонением двухслойной заготовки из разнородных металлов с использованием рельефа граничной поверхности. Используя теорию пластического течения разработана математическая модель деформирования прочесса совместной вытяэнки с утонением двух разнородных металлов с нагревом в условиях плоского деформированного состояния, которая позволила установить взаимосвязь параметров напряженно-деформированного состояния на граничной поверхности $и$ степени деформации утонения с исходными геометрическими параметрами заготовки, и проанализировать необходимые условия для заполнения рельефа граничной поверхности.

Ключевые слова: комплексная методика напряженно-деформированное состояние, компоненты напряжений и скоростей деформаций, разнородные металль, граничная поверхность, степень деформации, рельеф поверхности, вытяжка с утонением, двухслойная заготовка, исходные геометрические параметры заготовки.

\section{Забезпечення якості з'сднання шарів з різнорідних металів при виготовленні біметалевих трубчастих елементів витягуванням}

\section{P.С. Борис, В.А.Тітов}

Анотація. Запропонована комплексна методика теоретичного та експериментального дослідження прочесу виготовлення біметалевих трубчастих елементів витягуванням з потоншенням двотарової заготовки з різнорідних металів з використанням рельєфу граничної поверхні. Використовуючи теорію пластичної течії розроблена математична модель деформування прочесу сумісного витягування $з$ потоншенням двох різнорідних металів з нагрівом в умовах плоского деформованого стану, яка дозволила встановити взаємозв'язок параметрів напружено-деформованого стану на граничній поверхні і ступеню деформації потоншення з вихідними геометричними параметрами заготовки, та проаналізувати необхідні умови для заповнення рельєфу граничної поверхні.

Ключові слова: комплексна методика, напружено-деформований стан, компоненти напружень та швидкостей деформацій, різнорідні метали, гранична поверхня, ступінь деформації, рельєф поверхні, витягування з потоншенням, двомарова заготовка, вихідні геометричні параметри заготовки.

\section{References}

1. Aliieva, L., \& Zhbankov, Y. (2015). Radial-direct extrusion with a movable mandrel. Metallurgical and Mining Industry, (11), P. 175-183.

2. Тітов В. А. Витягування з потоншенням біметалевих трубчастих елементів з різнорідних металів і сплавів [текст]: монографія / В. А. Тітов, Р. С. Борис. - Київ: Центр учбової літератури, 2014. - 180 с.

3. Kalyuzhnyi, V.L., Aliieva, L.I., Kartamyshev, D.A., \& Savchinskii, I.G. (2017). Simulation of Cold Extrusion of Hollow Parts. Metallurgist, (61), P. 359-365.

4. Тітов В.А. Напрямки розвитку способів виготовлення біметалевих трубчастих елементів з різнорідних матеріалів витягуванням / В.А. Тітов, Р.С. Борис, М.С. Тривайло / Вісник НТУУ «КПІ», Серія машинобудування, Київ, 2009, №56. - C. 154-159.

5. Zhbankov, I., Perig, A., \& Aliieva, L. (2016) Calculation of recovery plasticity in multistage hot forging under isothermal conditions. Springer Plus, (69), P. 174-180. https://doi.org/10.1186/s40064-016-3570-x

6. Тітов В.А. Обгрунтування та реалізація дослідного процесу виготовлення біметалевих трубчастих елементів. / Тітов В.А., Борис Р.С., Вишневський П.С., Лук'яненко О.О. // Вісник НТУУ «КПІ», Серія машинобудування, Київ, 2010, №59. - C. 13-18.

7. Zhbankov, I.G., Perig, A.V., \& Aliieva, L.I. (2015). New schemes of forging plates, shafts and discs. Int. J. of Advanced Manufacturing Technology. (82), P. 287-301. DOI 10.1007/s00170-015-7377-7 
8. Алексеев Ю.Н. Вопросы пластического течения металлов / Ю.Н. Алексеев - Харьков, изд-во ХГУ, 1958. - 188c.

9. Тітов В.А. Розрахунок напружено-деформованого стану витягування 3 потоншенням ідеальнопластичного двошарового металу / Тітов В.А., Борис Р.С. // Обробка матеріалів тиском. - 2012. - №1 (30). - С. 45-52

10. Aliieva, L. \& Zhbankov, Y. (2015). Radial-direct extrusion with a movablemandrel. Metallurgical and Mining Industry, (11), P. 175-183.

11. Борис Р.С. Особливості врахування сил тертя при витягуванні з потоншенням двошарових заготовок / Борис Р.С., Титов В.А., Вишневский П.С. // Обработка материалов давлением. - 2012. - № 2 (31). \pm ПС. 22-29

12. Лимберг Э.А. Определение удельных давлений заполнения радиусов сопряжения в инструменте для объемной штамповки / Э.А. Лимберг, Г.Д. Селиванов // Обработка металлов давлением в машиностроении, вып. 17, 1981 C. $22-27$.

13. Zhou Li, Jingwei Zhao, Fanghui Jia, Qingfeng Zhang, Xiaojun Liang, Sihai Jiao, \& Zhengyi Jiang (2018). Analysis of bending characteristics of bimetal steel composite. International Journal of Mechanical Sciences, (148), P. 272-283.

14. Tallafuss, P., \& Johnston, J. (2018). Defects, causes and prevention controls in the continuous bronze/steel bimetal strip sintering process. Engineering Failure Analysis, (92), P. 32-43.

15. Wenming Jiang, Guangyu Li, Yao Wu, Xinwang Liu, \& Zitian Fan (2018). Effect of heat treatment on bonding strength of aluminum/steel bimetal produced by a compound casting. Journal of Materials Processing Technology. (258), P. $239-250$.

16. Hedayatia, O., Koreia, N., Adelia, M., \& Etminanbakhshb, M. (2017) / Microstructural evolution and interfacial diffusion during heat treatment of Hastelloy/stainless steel bimetals. Journal of Alloys and Compounds, (712), P. 172-178.

17. Inoue, J., Nambu, S., Ishimoto, Y., \& Koseki, T. (2008). Fracture elongation of brittle/ductile multilayered steel composites with a strong interface. Scripta Materialia, (59), P. 1055-1058.

18. Springer, H., Kostka, A., Payton, E.J., Raabe, D., Kaysser-Pyzalla, A., \& Eggeler, G. (2011). On the formation and growth of intermetallic phases during interdiffusion between lowcarbon steel and aluminum alloys. Acta Mater. (59), P. 1586-1600. https://doi.org/10.1016/j.actamat.2010.11.023

19. Springer, H., Szczepaniak, A., \& Raabe, D. (2015). On the role of zinc on the formation and growth of intermetallic phases during interdiffusion between steel and aluminium alloys. Acta Mater. (96), P. 203-211. https://doi.org/10.1016/j.actamat.2015.06.028

20. Viala, J.C., Peronnet, M., Barbeau, F., Bosselet, F., \& Bouix, J., (2002). Interface chemistry in aluminium alloy castings reinforced with iron base inserts. Compos. A., (33), P. 1417-1420.

21. Wang, T.M., Liang, C.H., Chen, Z.N., Zheng, Y.P., Kang, H.J., \& Wang, W., (2014). Development of an 8090/3003 bimetal slab using a modified. J. Mater. Process. Technol., (214), P. 1806-1811.

22. Xu, W.C., Zhang, Z.P., Huang, K., \& Shan, D.B., (2017). Effect of heat treatment and initial thickness ratio on spin bonding of 3A21/5A03 composite tube. J. Mater. Process. Technol. (247), P. 143-157.

23. Yang, T.Y., Wang, K.H., Zhang, D.K., Huang, J., (2017). Contact-reaction brazing of an AZ31 magnesium/3003 aluminum alloy using a silver-copper-zinc interlayer. J. Mater. Process. Technol., (249), P. 531-537.

24. Yin, F.C., Zhao, M.X., Liu, Y.X., Han, W., Li, Z., (2013). Effect of Si on growth kinetics of intermetallic compounds during reaction between solid iron and molten aluminum. Trans. Nonferrous Met. Soc. China, (23), P. 556-561. 